\title{
Marine Fuel Management Berbasis Android
}

\author{
Muhammad Hamdan \\ STMIK Atma Luhur \\ Jl. Jend. Sudirman, Selindung, Pangkalpinang \\ Kepulauan Bangka Belitung \\ dhani820@gmail.com
}

\author{
Ari Amir Alkodri \\ STMIK Atma Luhur \\ Jl. Jend. Sudirman, Selindung, Pangkalpinang \\ Kepulauan Bangka Belitung \\ arie_a3@atmaluhur.ac.id
}

\begin{abstract}
Abstrak - Aplikasi MFM secara umum adalah sebuah aplikasi perhitungan dengan tujuan untuk mengetahui bahan bakar pada kapal tanker. Dalam hal ini aplikasi ini tidak hanya digunakan untuk menghitung bahan bakar pada kapal tanker tapi juga digunakan sebagai media ditujukkan untuk perusahaan perkapalan. Perancangan dan pembangun perangkat lunak ini menggunakan sistem android dan metode waterfall . Aplikasi ini juga dibangun dengan menggunakan bahasa pemograman java dengan emulator eclipse juno. Hasil penelitian Perancangan dan Pembangun Perangkat Lunak ( Metode Waterfall) ini adalah alat media untuk menghitung pengguna volume bahan bakar yang setiap harinya terpakai pada kapal tanker dengan cara menjalankan smartphone Android dan untuk mengetahui jumlah tersisa volume bahan bakar pada kapal tanker tersebut.
\end{abstract}

Kata Kunci : Aplikasi Perhitungan, Android, Marine Fuel Management.

\section{Pendahuluan}

Marine Fuel Management adalah Suatu pendekatan secara bertingkat atau multi - level untuk pengukuran dan pelaporan penggunaan bahan - bakar dikapal, dengan sasaran pencapaian penguranngan penggunaan bahan-bakar, peningkatan efisiensi operasional dan perbaikan pengawasan manajemen armada. MFM telah berkembang dan menjadi begitu penting akibat kenaikan biaya bahan - bakar kapal dan meningkatnya tekanan - tekanan dari pemerintah untuk mengurangi pencemaran yang ditimbulkan oleh armada kapal di seluruh dunia.

\section{TINJAUAN PUSTAKA}

\section{A. Mesin Diesel}

Pada tahun 1892 seorang insinyur muda berkewenegaraan Jerman yang bernama Dr.Rudolf Diesel berhasil membuat mesin penyelaan kompresi menggunakan bahan bakar serbuk batubara dengan prinsip penyalaan bahan bakar dan udara. Akhirnya mesin diesel seperti ini keadaanya sekarang menjadi mesin yang benar- benar efisien, ringan dan bebas udara. Tahun 1900 dengan menggunakan minyak kacang (Bio Diesel), kemudian diperbaiki dan disempurnakan oleh (Charles F. Kettering). Mesin diesel merupakan salah satu hasil produksi yang dihasilkan proses yang sama seperti minyak solar dan mempunyai keunggulan yang sama untuk beberapa parameter spesifikasi antara lain : a. Cetane number yang tertinggi menghasilkan pembakaran yang lebih pada mesin.

b. Water content dan sulphur content yang sangat rendah sehingga mencegah dan mengurangi korosi. Minyak diesel biasa disebut juga sebagai Industrial Diesel Oil (IDO) atau Marine Diesel Fuel $(M D F)$.

\section{B. Multimedia}

Multimedia dapat dikatakan suatu bentuk baru dalam pembuatan program - program komputer dengan penggambungan lebih dari suatu media. Meskipun hanya mengandung sedikitnya dua elemen, sudah dikatakan multimedia. Pengertian multimedia menurut Rosch: "Multimedia adalah kombinasi dari komputer dan video"; Adapun pengertian menurut McCornick: "Multimedia secara umum merupakan kombinasi tiga elemen, yaitu suara, gambar dan teks.

\section{Interaksi Manusia Pada Komputer}

Interaksi manusia dan komputer adalah suatu displin ilmu yang mengkaji komunikasi ataupun interaksi antar pengguna dengan sistem komputer.

\section{Smartphone}

Dalam pengertian singkat, smartphone adalah sebuah device yang memungkinkan untuk melakukan komunikasi (seperti menelepon atau sms) juga di dalamnya terdapat fungsi PDA (Personal Digital Assistant) dan berkemampuan seperti layaknya computer.

\section{Metode Penelitian}

\section{A. Metode Pengumpulan Data}

\section{1) Studi Pustaka}

Merupakan teknik pengumpulan data atau informasi yang berbentuk literature berupa buku, jurnal, maupun $e$-book yang berkaitan dengan teori - teori multimedia, Android dan aplikasi design. 


\section{2) Wawancara}

Adalah suatu teknik pengumpulan data dengan mengadakan wawancara atau tanya jawab terhadapan berbagai sumber/pelaku yang terkait dengan pembangunan sistem yang akan dibangun.

\section{B. Analisa Sistem}

Aplikasi yang akan dibangun diberi nama "MFM" (Marine Fuel Manegement). Aplikasi "MFM" termasuk ke dalam jenis Aplikasi Perhitungan.Dengan didukung dengan rumus perhitungan yang melekat pada aplikasi ini bisa digunakan untuk semua orang yang menjalankan aplikasi ini. Pada tahapan ini dilakukan pengumpulan data -data apa saja yang dibutuhkan untuk membangun aplikasi yang dalam hal ini meliputin analisis sistem, analisis algoritma Fisher-Yates, serta analisis kebutuhan nonfungsional.

\section{Perancangan Sistem}

Pada tahap ini dilakukan perancangan aplikasi dan perancangan sistem. Tahap perancangan aplikasi berupa deskrip aplikasi dan komponen aplikasi. Tahap perancangan sistem berupa State Transition Diagram (STD).

\section{Pengkodean}

Pada tahap ini pengkodean perangkat lunak merupakan penulisan bahasa program agar perangkat lunak tersebut dapat dijalankan oleh mesin. Bahasa programan yang akan digunkan dalam sistem ini yaitu bahasa pemograman Java.

\section{E. Pengujian}

Pada tahap ini dilakukan pengujian perangkat lunak dengan cara menjalankan aplikasi di smartphone Android.

\section{HASIL DAN PEMBAHASAN}

\section{A. Perancangan Sistem}

Desain perancangan sistem pada aplikasi pengukuran terdiri dari empat komponen yaitu desain state transiton diagram (STD), desain Flowchart, dan rancangan tampilan antarmuka. Flowchart Login digunakan untuk menggambarkan image atau gambar yang muncul pada saat sebuah aplikasi atau program dalam proses loading, ditunjukkan pada Gambar 1. Flowchart Perhitungan digunakan untuk menerangkan langkah - langkah dari proses program. Pada saat program dimulai, program akan menampilkan menu yang terdiri dari Login, Perhitungan, Hasil, Logout, dan Exit, ditunjukkan pada Gambar 2. Pada diagram STD Pengukuran, pengguna akan langsung diarahkan ke halaman utama dari Aplikasi Pengukuran, dimana terdapat login, halaman utama, perhitungan, hasil, logout, exit, ditunjukkan pada Gambar 3.

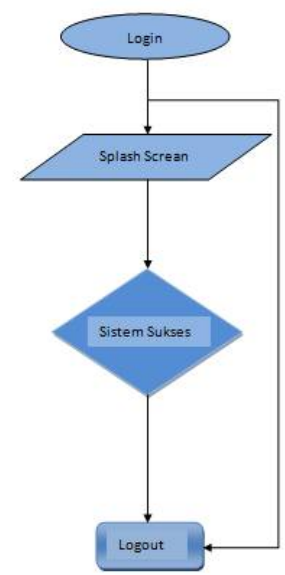

Gambar 1 Flowchart Login

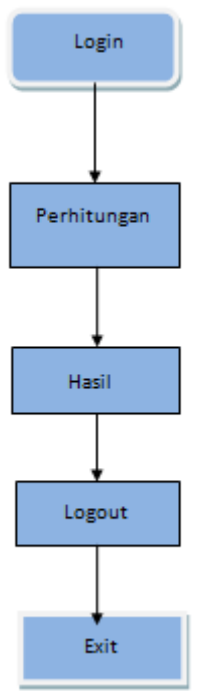

Gambar 2 Flowchart Perhitungan

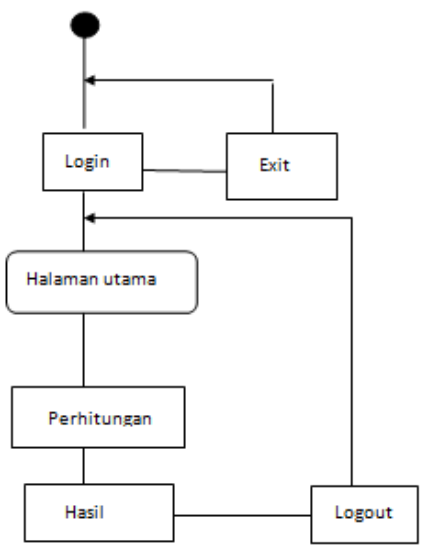

Gambar 3 STD Pengukuran 


\section{B. Rancangan Antar Muka}

Berikut ini adalah tampilan implementasi aplikasi berdasarkan kebutuhan dan perancangan sistem:

\section{Antarmuka Login}

Antarmuka login ini adalah tampilan awal saat masuk ke aplikasi pengukuran, ditunjukkan pada Gambar 4

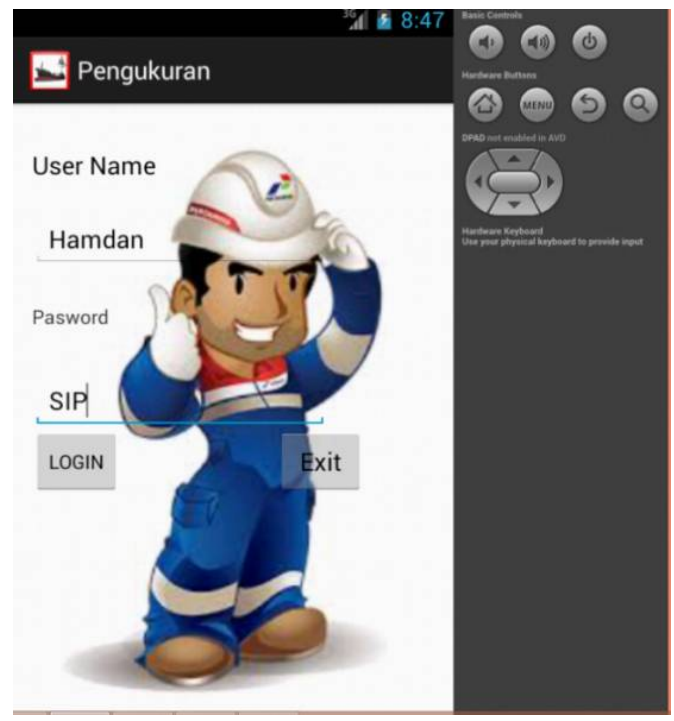

Gambar 4 Antarmuka Login

\section{Antarmuka Perhitungan}

Antarmuka perhitungan ini adalah tampilan menu utama aplikasi pengukuran, ditunjukkan pada Gambar 5.

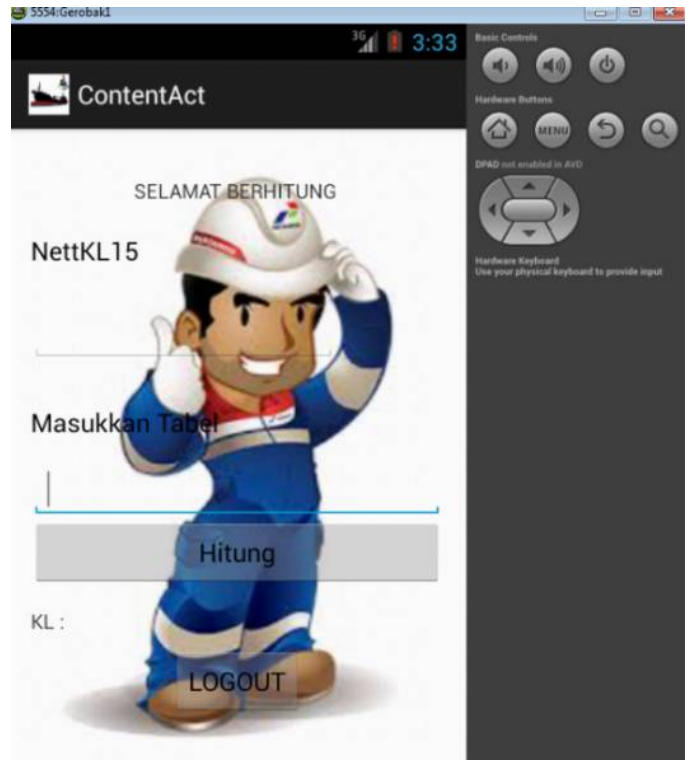

Gambar 5 Antarmuka Perhitungan

\section{Antarmuka Logout}

Antarmuka logout ini adalah tampilan keluar dari aplikasi perhitungan, ditunjukkan pada Gambar 6.

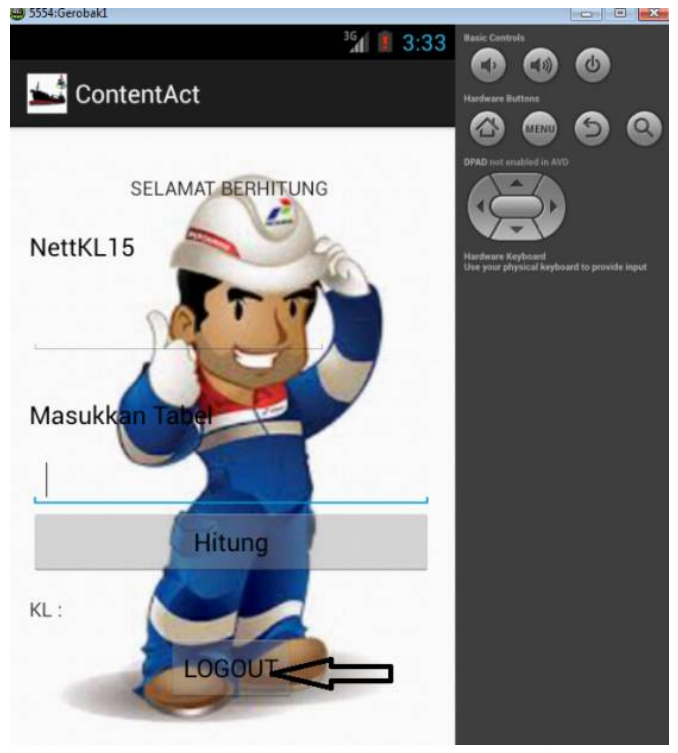

Gambar 6 Antarmuka Logout

\section{Antarmuka Exit}

Antarmuka exit ini adalah apakah penggunan ingin keluar dari aplikasi ini, ditunjukkan pada Gambar 7.

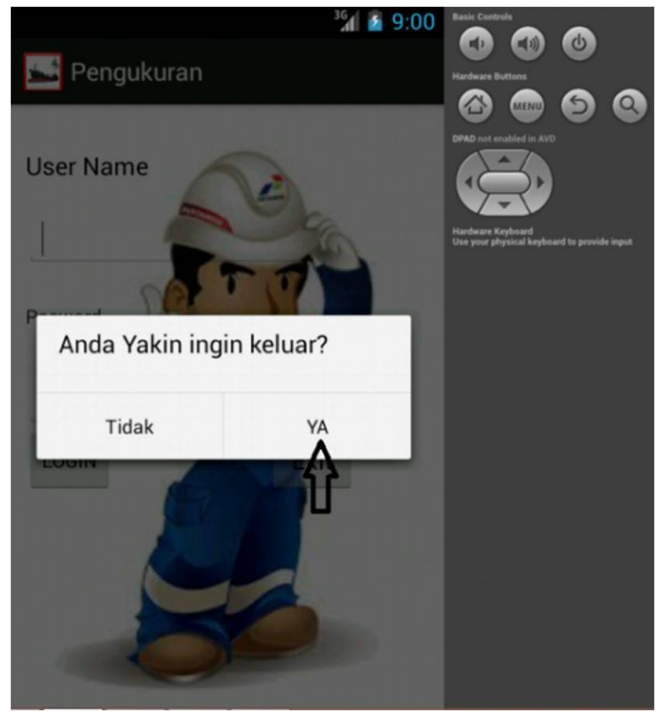

Gambar 7 Antarmuka Exit

\section{Pengujian}

Hasil pengujian ini menggunakan pengujian black box yang ditunjukkan pada Tabel 1 . 
Tabel 1 Hasil Pengujian Blackbox

\begin{tabular}{|c|c|c|c|}
\hline $\begin{array}{c}\text { Modul yang } \\
\text { diuji }\end{array}$ & $\begin{array}{c}\text { Teknik } \\
\text { Pengujian }\end{array}$ & Hasil & Kriteria \\
\hline $\begin{array}{c}\text { HalamanSplash } \\
\text { Screen }\end{array}$ & $\begin{array}{c}\text { Mengakses } \\
\text { Halaman menu } \\
\text { utama }\end{array}$ & $\begin{array}{c}\text { Menampilkan } \\
\text { Halaman menu } \\
\text { utama }\end{array}$ & $\mathrm{a}, \mathrm{b}$ \\
\hline $\begin{array}{c}\text { Halaman Menu } \\
\text { Utama }\end{array}$ & $\begin{array}{c}\text { Menghitung } \\
\text { volume bunker }\end{array}$ & $\begin{array}{c}\text { Menampilkan } \\
\text { hasil dari } \\
\text { perhitungan } \\
\text { bunker }\end{array}$ & $\mathrm{a}, \mathrm{b}$ \\
\hline Tampilan & Memilih menu & Menutup aplikasi & $\mathrm{a}, \mathrm{b}$ \\
Logout & exit & & \\
\hline
\end{tabular}

\section{Penutup}

Kesimpulan yang dapat diambil dari penelitian ini adalah sebagai berikut :

1. Aplikasi ini sangat bagus untuk menjadi salah satu media perhitungan volume bunker kapal.

2. Aplikasi MFM dapat digunakan tanpa adanya kesulitan oleh para penggunanya, sehingga aplikasi ini bisa digunakan untuk mencari volume bunker pada kapal.

3. Aplikasi MFM ini sudah diberi toleransi bagi perusahaan untuk pemakaian bunker pada kapal.

\section{DAFTAR PUSTAKA}

[1] Dr. Rudolf, 1892, "Theory and Construction of A Rational Heat Engine for Substitution of the Steam Engines and that Today Admitted Combustion Engines", Berlin, Jerman.

[2] Ebranda A. E, Mardiani, dan Tinaliah. (2013), Penerapan Metode Nä̈ve Bayes Untuk Sistem Klasifikasi SMS Pada Smartphone Android, STMIK MDP, Palembang.

[3] Kurniawati, S. Calvin, danYustina, M. (2012),Pengembangan Aplikasi Pembelajaran Bahasa Inggris Secara Self - Learning Pada Sistem Operasi Android, Skripsi S1., UNIKOM, Bandung.

[4] Kusumah, Adzie R,R. (2014), Pembangunan Aplikasi Game Kabayan Berhitung, Skripsi S1., UNIKOM, Bandung. 